\title{
Strengthening Performance Management System Implementation in South African Municipalities
}

Malefetsane Mofolo

\section{Abstract}

Aoption of a performance These reports called for the
management system in conceptualisation of a model that to
municipalities presented a serious strengthen the implementation in
challenge for its implementation. This municipalities of a performance
scenario is implicitly manifesting itself management system that is efficient
in the reports of the Auditor-General and effective. And most importantly,
on the financial statements and this model could be beneficial for
performance of municipalities, as well growth, development and effective
as in the state of local government in service delivery.
South Africa overview report (2009).

Keywords: Municipalities, Performance Management, System Implementation. 


\section{INTRODUCTION}

The concept of performance management is somewhat new in the South African public sector, particularly in municipalities. Curtis (1999:260) states that performance management is a set of management practices that are used in many countries around the world, such as Britain. Performance management was developed internationally about thirty years ago, and originated in the Management-by-Objectives (MBO) approach (Cameron \& Sewell, 2003:243). The concept was only introduced in South African municipalities in 1998 through the publication of the White Paper on Local Government.

Hughes (1998, in Cameron \& Sewell, 2003:243) further indicates that performance management was initially implemented in the private sector, but at present this management style is embedded and entrenched in the public sector's operations. The White Paper on Local Government (1998) and the resultant local government laws and regulations, which will be considered later in this article, state categorically how municipalities in South Africa should implement a performance management system.

Consequently, municipal systems of operations need to comply with legislatory requirements and provide frameworks through which service delivery can be realised. Thus, a performance management system is obligatory for municipalities.

The aim of this article is to propose a comprehensive approach that can be used to enhance performance in municipalities. The article also takes into consideration that the local government system is a new phenomenon in South Africa and is continuously evolving and therefore enhancements to the systems will be needed. The focus of this article is on organisational, departmental, and individual performance management.

\section{MUNICIPAL PERFORMANCE MANAGEMENT SYSTEM}

Performance management is a managerial task that includes activities that are meant to ensure that the goals and objectives of an organisation are consistently being achieved in an efficient and effective way (Wikipedia.org). Therefore managing performance in municipalities involves monitoring performance in relation to:

- key performance indicators (KPIs)

- the targets of development priorities

- objectives as laid down in the Integrated Development Plans (IDPs) 
- the subsequent measuring and reviewing of performance at least once a year as prescribed in the Municipal Systems Act, Act 32 of 2000.

According to Risher (2003:25), managers should be held accountable for creating an environment that strives for peak performance in municipalities. The indication is that in order for managers to create an environment that encourages good performance they should go beyond the basic aspects mentioned above which need monitoring, reviewing, and measuring in order to determine performance.

Meyer and Kirsten (2005:62) indicate that performance management would be beneficial to municipalities if it addresses the following objectives, which are to:

- create a supportive environment that promotes the culture of good performance

- establish clear performance standards

- ensure implementation of municipal development strategies

- provide performance feedback to employees

- promote the development of employees through training, counselling and coaching, in order to realise job opportunities

- improve career development by discussing municipal plans for career advancement and promotion

- improve communication and relationships by establishing mutual goals

- establish a framework for linking remuneration to performance

- improve the quality of services rendered by municipalities.

When the above performance management objectives as suggested are considered, it becomes obvious that management of performance should be comprehensive and strategic towards the promotion of effective service delivery. It is therefore relevant that at this juncture the prescriptions of the laws and regulations on this concept be highlighted so as to make sense of the legal expectations during the implementation of performance management in municipalities. Thus the next section focuses on the manner in which performance management should be implemented in South African local municipalities. 


\section{Laws and regulations regarding the municipal performance management system}

Chapter six of the Municipal Systems Act, Act 32 of 2000 concerns the manner in which municipalities should deal with performance management (Swanevelder, 2004:31). Sections 38-40 of the Act provide for the establishment of a performance management system that is appropriate to municipal resources; the development of a performance management system; and the manner in which the municipality should monitor and review its performance management system. As example, monitoring and review should focus on the efficacy of the system, particularly on its components.

Section 41 of the act spells out the core components of the municipal performance management system. These are the establishment of appropriate key performance indicators as a measure for performance; measurable performance targets with regard to the development priorities and objectives; monitoring, measuring and reviewing of performance; action to improve performance with regard to the development priorities and objectives where there is under-performance; and the creation of a regular mechanism reporting to the council, political structures, political office bearers, staff of the municipality, the public, and other organs of the state.

Section 42-48 of the act deal with the community involvement necessary to ensure the development, implementation and review of the municipality's performance management system and the manner in which the Minister should establish appropriate key performance indicators that can be applied to local government in general. This latter aspect is captured in the Municipal Planning and Performance Management Regulations (2001).

The Performance Management Guide for Municipalities (2001) presents guidelines on development and implementation of an organisational performance management system; at the same time it highlights some of the linkages to the employee or personnel performance management system, which should also form part of broader performance management systems in municipalities.

When considering the reports of the Auditor-General as highlighted by Duvenhage (2008:3) regarding the performance of municipalities and the findings of the State of Local Government in South Africa overview report (2009) as shown below, this article considers the implementation of municipal performance management systems to still be a serious challenge. The efforts at implementation need to be strengthened in order to promote the culture of good performance. 


\section{THE STATE OF PERFORMANCE IN MUNICIPALITIES}

The publication of reports by the Auditor-General on financial statements and the performance of municipalities shows that municipalities in South Africa are still struggling to perform efficiently and effectively. The root cause of this is the lack of internal controls and of governance principles, and the mismanagement in municipalities (Local Government Turnaround Strategy, 2009:11).

The South African Government has also admitted in Sake Rapport that some areas of mismanagement have occurred within public institutions (Duvenhage, 2008:3). This admission is contained in a report, which indicates that, according to past information about municipalities, $57 \%$ of financial statements for $2004 / 5$ were unsatisfactory. What is even worse is that the Government acknowledged the fact that great concern is voiced about the rendering of basic services to all South Africans (Duvenhage, 2008:3).

To this end, national state of local government assessments (State of Local Government in South Africa overview report, 2009:10) were conducted and they revealed that the difficulties in municipalities pointed, among others, to poor compliance with the legislative and regulatory frameworks. Furthermore, the State of Local Government in South Africa overview report (2009:30) indicates that in most municipalities performance management systems were either not established or not complied with. Over and above this, this report reveals that many municipal managers do not have signed performance contracts.

In view of these reports' findings, this article recommends a model to strengthen performance management system implementation in an attempt to alleviate shortcomings in municipalities.

\section{PROPOSED PERFORMANCE MANAGEMENT MODEL}

The performance management system in municipalities should assist employees by promoting an organisational culture in which groups or departments and individuals take the initiative for continuous improvement of their performance. It should also encourage employees to register with institutions of higher learning to improve their skills, which in the long run would enable them to perform efficiently and effectively. Learning is the basis of empowerment. Thus, performance management systems in municipalities should make use of recommended steps in the proposed model of a performance management system as shown in Figure 1 below. 
Figure 1: Proposed model of performance management system in Municipalities

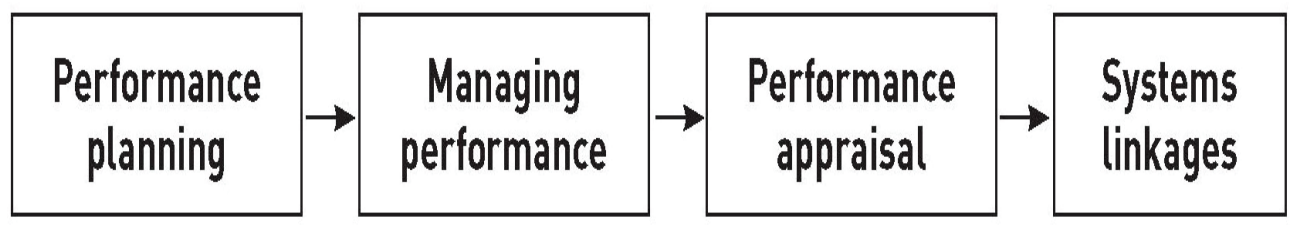

(Adapted from Meyer \& Kirsten, 2005:62)

The figure indicates the conceptual approach framework of separated, but related, performance managerial processes in the implementation of a performance management system. Primarily the model is applied to individual processes, yet its components lie at the heart of performance management as they integrate planning, action and monitoring, as well as evaluation to ensure continuous improvement and the achievement of service delivery objectives.

This model also accentuates the alignment of systems, since motivation, recruitment and promotion, and training and development of personnel are inherent organisational aspects for achieving effective performance in any organisation. These four steps of the model are discussed below.

\section{Performance planning}

Planning is a prerequisite for effective execution of performance management in any organisation (Meyer \& Kirsten, 2005:62). Therefore, performance management frameworks should be planned in such a way that they are based on key performance areas reflected in the Integrated Development Plans (IDPs) in municipalities (Municipal Finance Management Act, Act 56 of 2003). These frameworks should differentiate between organisational, departmental and individual performance management. This means that IDPs should be the basis for performance management systems, and should also serve as a tool to measure municipalities' performance (SALGA performance management series vol. 1).

Further than that, Service Delivery Budget Implementation Plans (SDBIPs) as a legislative requirement, and developed from the IDPs, should be used to measure departmental performance; and consequently, assistant managers should use monthly and quarterly workplace plans to measure individual performance (Municipal Finance Management Act, Act 56 of 2003).

The drawing up of monthly and quarterly workplace plans in departments or teams should be treated as a learning process by including and involving all 
employees working in departments or teams. During these meetings, employees should be given a clear understanding of municipal processes that relate and inform their goals at their respective levels. Blanchard (2007:97) asserts, "An important way to motivate your people is to make sure they know where they are going. See that each person's goals are clearly defined and that he or she knows what it means to perform well."

In this way, employees' roles and responsibilities should be clarified and monthly or quarterly workplace plans should relate to the goals and performance standards set in the SDBIPs for the individuals or teams in the department.

Table 1 below illustrates an example of a Service Delivery Budget Implementation Plan (SDBIP) template that could be used by municipalities as a performance plan in various departments, which could be used to measure departmental managers' performance.

Table 1: Example of Service Delivery Budget Implementation Plan (SDBIP) template

\begin{tabular}{|c|c|c|c|c|c|c|c|c|c|}
\hline \multirow{2}{*}{ KPA } & \multirow{2}{*}{ Objective } & \multirow{2}{*}{ KPI } & \multirow{2}{*}{$\begin{array}{l}\text { Baseline } \\
\text { indicator }\end{array}$} & \multirow{2}{*}{ Target } & \multirow{2}{*}{ Date } & \multirow{2}{*}{ Budget } & \multicolumn{3}{|l|}{ Responsibility } \\
\hline & & & & & & & Department & Section & Individual \\
\hline \multirow[t]{3}{*}{$\begin{array}{l}\text { Installation } \\
\text { of water } \\
\text { meters }\end{array}$} & \multirow[t]{3}{*}{$\begin{array}{l}\text { Accuracy of } \\
\text { measuring } \\
\text { water } \\
\text { consumption }\end{array}$} & $\begin{array}{l}\text { Installation } \\
\text { of } 90 \% \text { water } \\
\text { meters }\end{array}$ & $\begin{array}{l}10 \% \text { of } \\
\text { water meters } \\
\text { installed in } \\
\text { households }\end{array}$ & $\begin{array}{l}\text { Installation } \\
\text { of } 90 \% \text { water } \\
\text { meters }\end{array}$ & $30 / 06 / 08$ & $\mathrm{R} 2 \mathrm{~m}$ & Infrastructure & & $\begin{array}{l}\text { Departmental } \\
\text { manager } \\
\text { Senior manager }\end{array}$ \\
\hline & & $\begin{array}{l}\text { Availability of } \\
\text { water meters }\end{array}$ & $\begin{array}{l}10 \% \text { of water } \\
\text { meters in other } \\
\text { households }\end{array}$ & $\begin{array}{l}\text { Storing and } \\
\text { control of } \\
\text { water meters }\end{array}$ & $30 / 07 / 08$ & & Infrastructure & Stock & Stock controller \\
\hline & & $\begin{array}{l}\text { Installing } 8 \% \\
\text { water meters } \\
\text { per month }\end{array}$ & $\begin{array}{l}10 \% \text { of water } \\
\text { meters in other } \\
\text { households }\end{array}$ & $\begin{array}{l}\text { Installing } \\
90 \% \text { of water } \\
\text { meters }\end{array}$ & $\begin{array}{l}01 / 08 / 08 \\
\text { to } \\
30 / 06 / 109\end{array}$ & & Infrastructure & & General workers \\
\hline
\end{tabular}

(Adapted from SALGA performance management series volume 1)

As illustrated above, municipalities should use an SDBIP to manage the performance of departments. Individual performance management in every municipal department should be developed according to its SDBIP. The municipal manager and departmental managers, normally referred to as section 57 managers, should enter into annual performance agreements and have 
performance plans to keep track of their performance (Municipal Systems Act, Act 32 of 2000).

Performance plans should be developed together with annual performance agreements, and should clearly stipulate the performance requirements for a specific financial year. Through SDBIPs, departmental managers should enter into a performance agreement with municipal managers.

As illustrated in Table 1, information related to sections in a particular department, for example, the Department of Infrastructure/Technical services, should provide functional plans for the stock control section as well as for other relevant sections. In the same way, information related to general workers should also provide for an individual performance plan in that particular department, and should be reflected in the job descriptions of individuals. The performance plan should clearly identify tasks related to an individual staff member or a team for that specific financial year. In this way, job descriptions should be developed to manage and assess operational staff performance.

\section{Managing performance}

Management in municipalities should be aware that operational staff would not automatically implement performance plans and strive for defined standards or objectives. On the one hand, assistant managers should make themselves available and be able to guide and assist workers when problematic issues arise. On the other hand, operational staff needs necessary resources in order to perform as expected. Blanchard (2007:57) captures the foregoing sentiment explicitly by saying "being responsive to your people's needs sets them free to be responsible (able to respond) for getting the job done". Therefore, the required resources should be made available timeously. Furthermore, it is essential that assistant managers are able to provide continuous coaching to inspire and encourage staff members.

Departmental managers and assistant managers should also ensure that regular meetings are held where staff members report and voice their opinions about job-related issues. In order for operational staff to be effective, departmental managers and assistant managers should give them the freedom to carry out tasks independently and make decisions about work methods. Nonetheless, their independence should not be unrestricted; there must be guidelines that should serve as parameters within which they operate. Therefore all workers should be trained on those policy guidelines.

Meeting sessions should also be held to give staff members feedback concerning their performance. All errors revealed should be exposed and 
corrected. Operational staff members should also be encouraged to learn from their mistakes. These meetings should be treated as platforms to promote communication and a culture of good performance in municipalities. Thus, communication should serve as part of the performance management of departmental managers and assistant managers.

Since a performance appraisal relates to a performance management system, it should also be seriously considered to promote effective service delivery and to address developmental and training needs of employees in municipalities. Thus this aspect is discussed below.

\section{Performance appraisal}

Performance appraisal is a systematic and periodic process in which individual employees' performance is evaluated based on the predetermined goals and objectives of an organisation or department. It forms part of a performance management system, in that it ensures the availability and usage of precise and timeous assessment data, in order to recognise, reinforce or correct behaviour that can contribute to poor performance (Swanepoel, Erasmus, Van Wyk \& Schenk, 2003:372; Cameron \& Sewell, 2003:257). To this effect, a performance appraisal should be carried out as regular performance reviews during the course of the year towards an annual performance assessment in municipalities.

As part of the performance management system, a performance appraisal should concentrate on assessing performance outputs in relation to performance standards or objectives set in the Integrated Development Plans (IDPs), Service Delivery Budget Implementation Plans (SDBIPs) and job descriptions. Performance appraisal should assist municipalities to facilitate skills development and the competency of employees, creating a working culture and motivation, providing more communication channels, and identifying training and developmental needs (Bolton, 1997:129).

It is also recommended that the following people should administrate appraisal in municipalities:

- Mayors/councillors: should assess performance of the municipal council and the established committees, as well as that of administration

- Municipal managers: should assess performance of departmental managers or heads of departments (HODs) on a quarterly basis

- Departmental managers: should appraise performance of assistant managers on a quarterly basis 
- Municipal managers and departmental managers: should assess performance of the municipalities on a monthly basis

- Assistant managers: should assess performance of operational staff members reporting to them on a quarterly basis.

\section{Systems linkages}

In considering Cameron and Sewell's (2003:256) argument, it is important that municipalities encourage good performance. They should not focus on poor performance and subsequently take disciplinary action against employees, but rather take actions such as mentoring and developing, as well as encouraging good performance through rewards. In addition, municipalities should acknowledge good performance, in the event of employees who have successfully met or exceeded targets or objectives stipulated in the IDPs, SDBIPs, and job descriptions. The performance management system should be implemented as a tool or measure to reward performance in various ways; for example, financial rewards or recognition of achievement should be used in municipalities.

Thus, municipalities should consider developing reward systems that would assist and persuade employees to put more effort into their work and to perform as expected. Employees should also be informed about the way their efforts would be rewarded. This gesture would accentuate the importance of employees as partners in municipalities. For this reason, it is imperative for municipalities to treat employees as important assets. In order to achieve this, municipalities should develop reward systems policies that prescribe the kind of rewards that should be awarded to employees for good performance (Hersey, Blanchard \& Johnson, 2001: 211).

Furthermore, performance management systems should provide opportunities for employees' training and development for skills acquisition, so that they can be taken into consideration for promotion and for career paths available to them within municipalities. Personal development plans should be devised to address skills shortages. Over and above these issues, it is a matter of policy requirement that municipalities should continuously train and develop their employees to realise and achieve their visions, missions and strategic goals or objectives (Dessler, 1997:693; Municipal Systems Act, No. 32 of 2000).

The training and development in municipalities should thus be managed and directed, taking into consideration national policies and legislation. Managers in municipalities should have clarity of thought and be able to practise an inclusive 
approach to human resource (HR) management. Training and development should be based on effective human resource practices, such as the development of an HR plan for future filling of posts (through promotions, succession, career pathing, and recruitment from outside), establishment of job descriptions, as well as making use of results obtained from regular performance appraisal and performance management (c:Idocs \MM PDP 245 2006.doc).

It is also crucial that municipalities develop a performance management system as well as a development system that could update the personal development plans of employees. The purpose of a personal development plan is to identify, prioritise, and implement, training needs in municipalities. A recommended personal development plan is illustrated in Table 2 below.

\section{Table 2: Example of a development plan template}

Personal development plan of:

Mr/Mrs:

Compiled on (date):

\begin{tabular}{|c|c|c|c|c|c|c|}
\hline $\begin{array}{l}1 . \\
\text { Knowledge / } \\
\text { Skill Required }\end{array}$ & $\begin{array}{l}2 . \\
\text { Outcomes } \\
\text { expected }\end{array}$ & $\begin{array}{l}3 . \\
\text { Suggested } \\
\text { training / } \\
\text { development } \\
\text { activity }\end{array}$ & $\begin{array}{l}4 . \\
\text { Training } \\
\text { Institute }\end{array}$ & $\begin{array}{l}5 . \\
\text { Timeframe }\end{array}$ & $\begin{array}{l}6 . \\
\text { Work } \\
\text { Opportunity } \\
\text { to practice } \\
\text { knowledge / } \\
\text { skills }\end{array}$ & $\begin{array}{l}7 . \\
\text { Mentor }\end{array}$ \\
\hline $\begin{array}{l}\text { a] } \\
\text { Performance } \\
\text { Management }\end{array}$ & $\begin{array}{l}\text { The manager } \\
\text { will be able to } \\
\text { measure } \\
\text { performance } \\
\text { of staff }\end{array}$ & $\begin{array}{l}\text { A course on } \\
\text { performance } \\
\text { management }\end{array}$ & $\begin{array}{l}\text { External } \\
\text { service } \\
\text { provider, } \\
\text { based on } \\
\text { identified } \\
\text { unit } \\
\text { standards }\end{array}$ & Feb 2009 & $\begin{array}{l}\text { Assess } \\
\text { performance } \\
\text { of operation } \\
\text { staff }\end{array}$ & $\begin{array}{l}\text { Departmental } \\
\text { Manager }\end{array}$ \\
\hline \multicolumn{7}{|l|}{ [b] } \\
\hline [c] & & & & & & \\
\hline
\end{tabular}

(Adapted from c:IdocsIMM PDP 245 2006.doc) 
A personal development plan should:

- identify expected outcomes and time frames for achievement of such outcomes

- recommend training and development activities

- recommend a training institute

- recommend the way acquired knowledge and skill should be practised in the workplace

- allocate or mention a mentor.

Therefore it is important that all employees in municipalities should draft personal development plans. For section 57 managers, personal development plans should form part of their annual performance agreements, and these plans should be concluded at the beginning of the performance cycle or financial year.

In order to address their individual training needs, municipalities should compile workplace skills plans to serve as a basis for all training and education activities for employees in a specific financial year. Since there are external organisations that assist municipalities to train employees, it is important that municipal management should ensure that training and education activities provided by an external provider are relevant to the identified unit standards in order for municipal employees to be able to accumulate credits towards qualifications over time.

Unit standards refer to registered statements of desired education and training outcomes and their associated assessment criteria, as well as administrative and other information as specified in the regulations (Open Learning Group, Training the Assessor Learner Guide, 2005:23). Therefore, for municipalities to achieve the needed education and training, these should be aligned with the Local Government Education and Training Authority (LGSeta). This would enable municipalities to address the scarce skills exposed during the national state of local government assessments (State of Local Government in South Africa Overview Report, 2009:32).

\section{CONCLUSION}

It can be concluded that strengthening the performance management system could be the basis of effective service delivery in municipalities. As shown from the findings on the Auditor-General's reports and state of Local Government in South Africa Overview Report (2009), a serious challenge is posed in implementing a municipal performance management system to promote the 
culture of good performance in municipalities. As highlighted by Kroukamp (2007:27), the challenge of local government relates to an effective way of measuring organisational excellence that is both understood and accepted nationally and internationally.

Therefore municipalities should establish a comprehensive way of measuring and managing performance, since it would not serve any purpose to only assess the end product or service. Monitoring and evaluation of processes towards the outcomes are critical. It is in this regard that more rigorous activities should be integrated in the performance management systems of municipalities in South Africa in order to improve performance. The recommended model could serve as a guideline to improve the performance of local government.

\section{List of References}

- Blanchard, K. 2007. The heart of a leader: Insights on the art of influence (2nd ed.). Colorado Springs: David C. Cook.

- Bolton, T. 1997. Human resource management: An introduction. Cambridge: Blackwell Publishers Ltd.

- Cameron, R. \& Sewell, B. 2003. The implementation of performance management in the Cape Town Municipality: 1996-2000. SAJEMS NS, 6(2):243261.

- Curtis, D. 1999. Performance management for participatory democracy: Thoughts on the transformation process in South African local government. International Journal of Public Sector Management, 12(3):260-272.

- Dessler, G. 1997. Human resource management. (7th ed.). New Jersey: PrenticeHall, Inc.

- Duvenhage, H. 2008. Korrupsie groter probleem. Sake Rapport, 17 August 2008.

- Hersey, P., Blanchard, K.H. \& Johnson, D.E. 2001. Management of organisational behaviour: Leading human resources. (8th ed.). California: Prentice Hall, Inc.

- http://en.wikipedia.org/wiki/Performance management (Accessed 25 May 2012).

- Kroukamp, H. 2007. South African local government performance: Satisfactory to be globally competitive? Journal for New Generation Sciences, vol. 6, no. 1:1631. 
- Meyer, M. \& Kirsten, M. 2005. Introduction to Human Resource Management. Claremont: NAE.

- Open Learning Group Training 2005. Learner Workbook - US 115753: Training the Assessor Portfolio Guide. Open learning College.

- Personal Development Plan (PDP). 2006. Available at: c:Idocs MMM PDP 245 2006.doc (Accessed 24 October 2007].

- Risher, H. 2003. Refocusing performance management for high performance. Compensation and Benefits Review. Wharton: Centre for Human Resources.

- South Africa. 1998. Department of Provincial and Local Government. White Paper on Local Government. Pretoria: Government Printers.

- South Africa. 2000. The Municipal Systems Act, Act 32 of 2000. Pretoria: Government Printers.

- South Africa. 2001. Municipal Planning and Performance Management Regulations. Department of Provincial and Local Government. Pretoria: Government Printers.

- South Africa.. 2001. Performance Management Guide for Municipalities. Department of Provincial and Local Government. Pretoria: Government Printers.

- South Africa.. 2003. Municipal Finance Management Act, Act 56 of 2003. Pretoria: Government Printers.

- South Africa. 2009. State of local government in South Africa: Overview report. Pretoria: Government Printers.

- South Africa. 2009. Local Government Turnaround Strategy: Working together, turning the tide in local government. Pretoria: Government Printers.

- Swanepoel, B., Erasmus, B., Van Wyk, M. \& Schenk, H. 2003. South African human resource management: Theory and practice. (3rd ed.). Cape Town: Juta.

- Swanevelder, J.J. 2004. Performance measures for municipalities. Official ournal of Municipal Financial Officers, 30-32, Spring.

\section{AUTHOR'S CONTACTS:}

\section{Malefetsane Mofolo}

Faculty of Management Sciences, Governance \& Public Management

Walter Sisulu University of Technology

mmofolo@wsu.ac.za 